\title{
Importância do Ensino Prático
}

"Como as Lições Teoréticas nesta Ciência [Química] não podem ser bem compreendidas, sem a prática delas; deverá o Professor (...) [dar] as Lições competentes de Prática no Laboratório; nas quais não fará dos seus Discípulos meros espectadores; mas sim os obrigará a trabalhar nas mesmas Experiências, para se formarem no gosto de observarem a Natureza; e de contribuirem por si mesmos ao adiantamento, e progresso desta Ciência. A qual não se enriquece com Sistemas vãos, e especulações ociosas, mas com descobrimentos reais, que não se acham doutro modo, senão observando, experimentando e trabalhando. O Lente será por isso obrigado a dar por si mesmo aos seus Discípulos exemplo do trabalho, e constância, que se requerem no Observatório da Natureza.»

dos Estatutos da Universidade de Coimbra (1772)

"Os trabalhos de laboratório, por seu lado, desenvolvem a destreza manual do aluno e as suas faculdades de observação; põem-no em contacto com os factos em que se baseiam as concepções teóricas; levam-no ao conhecimento prático dos processos de investigação científica, dotando-o ainda com o senso crítico que permite avaliar o crédito que merecem as teorias, segundo o número e o rigor das observações em que se baseiam. No espírito do aluno, o facto observado toma então o seu verdadeiro lugar, como parte do alicerce da ciência, e o seu saber deixa de ser um amálgama de coisas imperfeitamente assi- miladas, para se transformar em parcela integrante da sua individualidade." (...) "As ciências têm geralmente as suas técnicas especiais, cujo conhecimento prático é tão necessário como o das teorias; estas poderá ainda o aluno conhecê-las pela exposição oral; mas os métodos científicos de investigação, cujo ensino representa a parte mais importante e característica dos cursos superiores, só se adquirem por tirocínio prático sob a direcção de um mestre, porque a educação científica é sobretudo uma questão de contágio [Le Chatelier]." (...) «Outra circunstância que dificulta igualmente a organização do ensino prático profícuo resulta indirectamente do nosso culto mais ou menos inconsciente pelo verbalismo. Aceita-se tacitamente a ideia de que o ensino verbal constitui uma função mais elevada e mais difícil do que ensinar praticamente como se aplicam as teorias a casos concretos, quando é justamente o contrário, na maioria dos casos, o que corresponde à verdade. Este critério errado conduz à tendência nociva de abandonar inteiramente ao assistente o ensino prático, falsamente tido por mais simples, reservando o professor para si, mais ou menos exclusivamente, a exposição oral. A função do professor deveria dividir-se normalmente em duas partes de igual importância: a prelecção, em que expõe os traços gerais da ciência como um todo harmónico, (...) e os exercícios de aplicação dos métodos de investigação científica. É na segunda parte que o bom professor será geralmente insubstituível.»

\section{A. Bensaúde, in Notas Histórico-Pedagógicas} sobre o Instituto Superior Técnico (1922). 